\title{
PEMIKIRAN ABDUL QADIM ZALLUM TENTANG MAJELIS UMAT DAN DEWAN PERWAKILAN RAKYAT DI INDONESIA
}

\author{
M. Syamsul Arifin \\ Universitas Islam Negeri Sunan Ampel, Jl. A. Yani I I 7 Surabaya | judulsj@gmail.com
}

\begin{abstract}
This article describes the conception of Majelis Umat according to Abdul Qadim Zallum and conception of the DPR under the Constitution of 1945. In Abdul Qadim Zallum's thought, the conception of Majelis Umat and the DPR basically is a representative of the people in each form of the state, but in conception of Majelis Umat the representativeness of race is limited, such as in the establishment of the law, a people representative of the non-Muslims can't contribute to the perfection of the law because they are not representative for analizyng Islamic law, so is the Majelis Umat in his opinion (most votes) is not binding for the Caliph, with other words Majelis Umat don't have any authority in law as having law is God. In the conception of DPR, any issues relating to the welfare of the people being their authority, certainly not without the approval of the President as the leader of the government. So the differences that really stands out is the authority of the Majelis Umat who are severely restricted by the Caliph and shariah law itself. While in DPR based on the Constitution of 1945, as long as not contrary to the basis of the country, DPR has the right to request the approval of the President.
\end{abstract}

Keywords: Majelis Umat, the conception, DPR, Abdul Qadim Zallum

Abstrak: Artikel ini menjelaskan tentang konsepsi majelis umat menurut Abdul Qadim Zallum dan konsepsi Dewan Perwakilan Rakyat menurut Undang-undang 1945. Dalam pemikiran Abdul Qadim Zallum, konsepsi Majelis Umat dan DPR pada dasarnya adalah merupakan wakil rakyat dalam masing-masing bentuk negara, tapi dalam konsepsi majelis umat keterwakilannya terbatas, seperti dalam pembentukan Undang-undang seorang wakil dari kaum nonmuslim tidak dapat memberikan sumbangsih terhadap kesempurnaan hukum karena dianggap tidak representatif untuk menganalisis hukum Islam, begitu juga majelis umat dalam pendapatnya (suara terbanyak) tidak 
mengikat bagi Khalifah, dengan kata lain majelis umat tidak mempunyai kewenangan apapun dalam perundang-undangan karena yang mempunyai hukum adalah Allah. Dalam konsepsi DPR, setiap persoalan yang berkaitan dengan kesejahteraan rakyat, ini menjadi kewenangan mereka, tentunya tidak terlepas dari persetujuan Presiden sebagai pemimpin pemerintah. Jadi perbedaan yang sangat menonjol adalah kewenangan majelis umat yang sangat dibatasi oleh Khalifah dan hukum syari'at sendiri. Sedangkan dalam DPR berlandaskan pada Undang-undang Dasar 1945, sepanjang tidak bertentangan dengan dasar negara ini, tetap DPR mempunyai hak untuk meminta persetujuan dari Presiden.

Kata Kunci: Majelis Umat, konsepsi, DPR, Abdul Qadim Zallum

\section{Pendahuluan}

Islam merupakan risalah yang paripurna dan universal. Islam sangat kompleks, mengatur seluruh masalah kehidupan, serta hubungan antara manusia dengan Tuhan sebagai sang Khalik dan hubungan antar manusia sebagai relasi kehidupan, baik dalam konteks individu maupun secara kolektif. Begitu pula Islam mampu menyelesaikan seluruh problem interaksi di dalam negara dan masyarakat, baik dalam masalah pemerintahan, ekonomi, sosial, pendidikan maupun politik. ${ }^{1}$

Pada dasarnya, sejak awal kemunculan Islam sudah mengatur pola hubungan sosial. Ketika itu, Nabi Muhammad dan kaum muslimin pindah dari Mekah ke Madinah pada tahun 622 Masehi, di sana membangun komunitas baru yaitu kaum Muhajirin (orangorang yang pindah dari mekah) dan kaum Ansar (para penolong). Masa itu di Jazirah Arab hanya ada satu model komunitas, komunitas suku yang didasarkan pada pertalian darah. Namun dengan datangnya kaum Muhajirin maka model tersebut berubah menjadi hubungan keyakinan (religius).

Lambat laun terjadi pergeseran, misalnya pergulatan politik dengan agama yang di dalamnya terdapat doktrin bahwa politik merupakan bagian integral dari agama. Sebagai akibatnya, politik 
menjadi suatu kewajiban keagamaan, bahkan menurut doktrin Syi'ah, politik harus dilihat sebagai pilar keenam dari Islam, di samping lima pilar yang umum diketahui. ${ }^{2}$

Menurut Abdul Qadim Zallum, politik adalah bagian integral dari akidah Islam yang akan mengatur urusan umat. Maka dari itu, negara atau sistem pemerintahan harus berpedoman pada akidah Islam. Akidah Islam memberikan hukum dan pemikiran yang memperhatikan semua urusan kehidupan dan hubungan manusia di dalamnya, yang berkaitan dengan masalah pemerintahan, ekonomi, hubungan sosial, pendidikan politik dalam dan luar negeri maupun hubungan penguasa dengan rakyatnya. ${ }^{3}$

Sistem pemerintahan Islam berdiri atas pilar akidah Islam serta hukum-hukum syara', kedaulatannya di tangan syara', bukan di tangan umat. Dalam hal ini, baik umat maupun Khalifah tidak mempunyai hak untuk membuat aturan sendiri. Karena yang berhak membuat aturan hanyalah Allah swt. Sedangkan Khalifah memiliki hak mengadopsi hukum-hukum untuk dijadikan sebagai undang-undang dasar serta perundang-undangan dari kitabullah dan sunah Rasul. Begitu pula umat tidak berhak untuk memecat Khalifah karena yang berhak hanyalah syara'. Akan tetapi umat tetap berhak untuk mengangkatnya. ${ }^{4}$

Negara yang menganut sistem republik, kepala negara atau presiden bertanggung jawab kepada rakyat atau yang mewakili suara rakyat. Rakyat beserta wakilnya berhak memberhentikan presiden, karena kedaulatan di tangan rakyat. Sedangkan dalam sistem negara Islam, karena seorang Khalifah, sekalipun bertanggung jawab di hadapan umat serta wakil-wakilnya, termasuk menerima kritik dan koreksi dari umat dan wakilwakilnya, namun umat termasuk para wakilnya tidak berhak

\footnotetext{
2 Ulil Abshar Abdallah, Islam dan Barat (Demokrasi dalam Masyarakat Islam), (Jakarta: Diterbitkan kerjasama Friedrich-Nauman-Stiftung Indonesia dan Pusat Studi Islam Paramadina, 2002), 8.

${ }^{3}$ Abdul Qadim Zallum, Sistem Pemerintahan Islam, 6.

${ }^{4}$ Ibid., 30.
} 
untuk memberhentikan Khalifah. Khalifah tidak akan diberhentikan kecuali menyimpang dari hukum syara' yang menjadi landasan negara. Adapun yang menentukan pemberhentian Khalifah adalah Mahkamah Mazalim. ${ }^{5}$

Untuk menjaga stabilitas negara Islam, ada beberapa lembaga yang menjadi penyeimbang dan menjadi badan yang berfungsi sebagai kontrol dan mengoreksi terhadap penguasa (Khalifah) dalam menjalankan sistem kenegaraan, apakah sudah sesuai dengan kepentingan rakyat atau tidak. Lembaga tersebut adalah Majelis Umat. Lembaga ini menjadi badan legislatif yang mempunyai hak untuk memberi koreksi dan kontrol terhadap tugas-tugas dan kebijakan-kebijakan penguasa. Di samping itu, Majelis Umat mempunyai hak syura atau menyampaikan pendapat. Tentunya dalam keanggotaan Majelis Umat ada prosedur yang mengaturnya. Mulai pengangkatan, masa keanggotaan, siapa yang berhak menjadi anggota, dan seberapa besar pengaruh dan wewenang dari lembaga tersebut.

Seperti halnya dalam negara yang menganut sistem Khilafah, negara yang tegak berdiri di atas sistem demokrasi, Indonesia misalnya ada lembaga legislatif yaitu DPR yang dipilih langsung oleh rakyat. Peranan DPR diartikan sebagai aktifitas yang dilakukan oleh berbagai unsur DPR seperti anggota, pimpinan, fraksi, komisi, dan badan kelengkapan DPR secara sendiri-sendiri atau secara bersama-sama yang dilakukan dalam rangka melaksanakan fungsi-fungsi badan tersebut. Dalam hal ini DPR bertindak sebagai pelindung kepentingan dan penyalur aspirasi anggota masyarakat yang diwakilinya. ${ }^{6}$ Keanggotaan Dewan Perwakilan Rakyat (DPR) ini sudah diatur dalam Undang-undang 1945, Bab VIIA/B, baik pengangkatan, wewenang, fungsi dan masa jabatannya. ${ }^{7}$

${ }^{5}$ lbid.

${ }^{6}$ Arbi Sanit, Perwakilan Politik di Indonesia, (Jakarta: Rajawali, 1985), 252-253.

${ }^{7}$ Undang Undang Dasar 1945, 13-14. 
Dari kedua konsepsi tersebut yaitu Majelis Umat dan DPR, penulis ingin menganalisa persamaan dan perbedaan dari konsep tersebut menurut pemikiran Abdul Qadim Zallum dan Undangundang Dasar 1945, untuk dijadikan sebagai kontribusi keilmuan.

\section{Biografi Abdul Qadim Zallum}

Syaikh Abdul Qadim Zallum memiliki nama lengkap Abdul Qadim bin Yusuf bin Abdul Qadim bin Yunus bin Ibrahim. Ia lahir pada tahun 1924 M di Kota al-Khalil, Palestina. Ia berasal dari keluarga yang dikenal luas dan terkenal keberagamaannya (religius). Ayahnya seorang penghafal al-Quran dan bekerja sebagai guru pada masa Dawlah al-Khilafah Usmaniyah. Paman ayahnya, Syaikh Abdul Ghafar Yunus Zallum, adalah mufti alKhalil pada masa Daulah al-Khilafah Usmaniyah. Keluarga Syaikh Zallum termasuk keluarga yang memelihara dan mengurus Masjid al-Ibrahimi al-Khalil. Mereka memelihara (peninggalan) Nabi Ya'qub as. dan menjadi Khatib Jum'at dan hari-hari raya.

Syaikh Abdul Qadim Zallum tumbuh dan berkembang di kota al-Khalil hingga mencapai usia 15 tahun. Ia menempuh pendidikan dasar di Madrasah al-Ibrahimiyah di al-Khalil. Kemudian ayahnya mengirimnya ke al-Azhar asy-Syarif untuk mempelajari fikih. Setelah genap berusia 15 tahun, ayahnya mengirimnya ke Universitas al-Azhar Kairo pada tahun 1939 M. Ia memperoleh ijazah al-Ahliyyah al-Ghila pada tahun $1942 \mathrm{M}$. Kemudian memperoleh ijazah Pendidikan Tinggi Universitas alAzhar pada tahun 1947. Kemudian memperoleh ijazah dalam bidang keahlian al-Qadha' (peradilan), seperti ijazah doktor sekarang ini, pada tahun $1949 \mathrm{M}$ di Universitas yang sama.

Ketika kembali ke al-Khalil pada tahun 1949 M, Zallum diangkat menjadi guru di Madrasah Bait al-Lahem selama beberapa tahun. Kemudian pindah ke al-Khalil pada tahun 1951 dan bekerja sebagai guru di Madrasah Usamah bin Munqidz. Pada tahun 1952, ia berjumpa dengan Syaikh Taqiyuddin an-Nabhani. Lalu ia pergi ke al-Quds untuk bergabung dengan Syaikh

\section{Vol. 4. no.2. Oktober 2014}


Taqiyuddin dan melakukan kajian serta berdiskusi seputar masalah partai (Hizbut Tahrir). Ia kemudian bergabung dengan Hizbut Tahrir dan menjadi anggota qiyadah Hizbut Tahrir sejak tahun 1956 M. Ia adalah seorang orator ulung sekaligus dicintai oleh masyarakat.

Ia pernah ditangkap dan dijebloskan di penjara al-Jafar ashShahrawi (penjara di padang pasir yang berada di al-Jafar, bagian selatan Yordania, khusus untuk para tahanan politik). Ia menempati penjara itu selama beberapa tahun. ${ }^{8}$

Syaikh Zallum merupakan kepercayaan Syaikh Taqiyuddin an-Nabhani, amir pendiri Hizbut Tahrir. Syaikh Taqiyuddin sering mengutusnya untuk beberapa tugas besar. Ketika Syaikh Taqiyuddin an-Nabhani wafat pada tahun 1977 M, Syaikh Zallum terpilih untuk mengemban amanah sesudahnya.

Aktivitas Hizbut Tahrir pada masanya menjadi besar karena bertambah banyaknya jumlah anggota. Jangkauan Hizbut Tahrir juga meluas mencapai banyak negara di dunia, termasuk Asia Tengah dan Asia Tenggara. Bahkan gaung dakwah bergema di Eropa dan benua lainnya. Hizbut Tahrir berhasil mengorganisasi dan menghimpun ribuan syabab Muslim. Ketika diumumkan (rencana) Pemilu anggota parlemen pada tahun $1954 \mathrm{M}$, ia mencalonkan diri di Kota al-Khalil. Begitu juga pada tahun 1956. Akan tetapi, di kedua Pemilu itu ia tidak berhasil menjadi anggota parlemen karena kecurangan berupa pemalsuan hasil Pemilu yang dilakukan oleh negara.

Syaikh Zallum terus mengemban dakwah dan kepemimpinan Hizbut Tahrir hingga mencapai usia lebih dari 80 tahun. Sekitar 25 tahun ia menjadi kepercayaan Syaikh Taqiyuddin an-Nabhani, dan kurang lebih selama 25 tahun, ia memimpin perjalanan Hizbut Tahrir sebagai amir Hizbut Tahrir. Ia lalu mengundurkan diri dari kepemimpinan Hizbut Tahrir pada tanggal 17 Maret 2003 M. Lalu

${ }^{8}$ htt:/zantrum-demokratische-kultur.de/pdf/hisbut.pdf. 
sekitar 40 hari setelah itu, ia wafat di Beirut pada tanggal 29 April 2003 M dalam usia lebih dari 80 tahun. $^{9}$

\section{Pemikiran Abdul Qadim Zallum tentang Politik dan Demokrasi}

Pemikiran politik adalah pemikiran yang berkaitan dengan pengaturan dan pemeliharaan urusan umat. Akidah Islam merupakan suatu pemikiran politik. Oleh karena itu, ia harus menjadi pondasi bagi pemikiran politik kaum muslim.

Perbedaan akidah Islam dengan akidah dan ideologi yang lain adalah akidah Islam merupakan akidah politik dan spiritual. Hukum-hukum dan pemikiran yang bersumber darinya menekankan perhatiannya pada urusan dunia dan sekaligus urusan akhirat. Akidah Islam mengatur semua urusan dan hubungan dalam ruang lingkup sistem sosial kemasyarakatan, baik yang berkenaan dengan pemerintahan, ekonomi, hubungan sosial, pendidikan, politik dalam dan luar negeri maupun hubungan penguasa dengan rakyatnya. ${ }^{10}$

Akidah Islam mewajibkan umat Islam berperan aktif dalam aktifitas apapun, baik dalam partai, kelompok, organisasi, untuk memperjuangkan kehidupan Islami dan menyampaikan dakwah Islam. Politik merupakan seni untuk memahami realitas yang mungkin terjadi kemudian hari. Oleh sebab itu, keterlibatan dalam politik menjadi kewajiban bagi setiap komponen masyarakat Muslim. ${ }^{11}$

Rakyat mempunyai hak koreksi terhadap penguasa. Untuk melaksanakan tugasnya dalam kehidupan politik yaitu mengoreksi penguasa (pemerintah) tidak akan terlaksana dengan sempurna tanpa memahami sikap dan aktivitasnya. Jika sikap dan aktivitasnya tidak dapat diketahui dengan pasti, maka mustahil bagi kaum Muslim untuk dapat melaksanakan aktivitas politik secara sempurna. Dengan dasar tersebut, melaksanakan aktivitas

\footnotetext{
${ }^{9}$ http.fahmy-ramadhan

${ }^{10}$ Abdul Qadim Zallum, Pemikiran Politik Islam, (Bangil: Al-Izzah, 200 I), 6.

"I Ibid., I 15.
} 
politik, baik urusan internal maupun eksternal akan menjadi wajib atau fardu kifayah atas kaum muslimin. ${ }^{12}$

Hukum dari aktivitas politik menjadi kewajiban bagi kaum muslimin. Begitu juga dalam bentuk sistem yang mengatur kehidupan sehari-hari, baik yang berurusan dengan sesama ataupun urusan dengan pemerintahan telah diatur dengan lengkap oleh hukum Islam itu sendiri.

Demokrasi adalah sistem yang dianut manusia pada zaman dulu. Pada saat itu, umat mengalami keresahan sosial akibat penindasan dari pemerintah yang mengaku dirinya sebagai wakil Tuhan di muka bumi. Sebagai reaksinya, para filosof dan pemikir mendiskusikan problematika pemerintahan dan kemudian menyusun sistem untuk memerintah umat manusia. Sistem itu disebut sistem demokrasi. Dengan demikian, demokrasi diciptakan untuk membebaskan manusia dari penindasan pemerintah yang zalim. Sistem demokrasi menyatakan bahwa penguasa mendapatkan kekuasaannya dari manusia (rakyat) bukan dari Tuhan. Demokrasi adalah ide yang disebarluaskan negara-negara barat dalam invasi budaya mereka ke negaranegara kaum muslim. ${ }^{13}$

Islam (versi Abdul Qadim Zallum) mengharamkan sistem demokrasi dengan tiga alasan: pertama, ide demokrasi diciptakan oleh negara-negara kafir Barat. Hal ini merupakan bentuk agresi budaya Barat ke negeri kaum muslim. Kedua, demokrasi adalah pemikiran yang utopis, yang tidak layak diimplementasikan. Jika ide demokrasi itu akan dilaksanakan, maka seringkali harus melakukan kebohongan. Parlemen tidak menyusun hukum dan perundang-undangan, justru pemerintah yang mengajukan rancangan undang-undang, sementara parlemen hanya tinggal memberikan persetujuan. Ketiga, sistem demokrasi adalah produk manusia. Sistem tersebut dibuat manusia untuk manusia, padahal manusia rentan dengan kesalahan, hanya Allah yang tidak pernah

12 Ibid., 197.
${ }^{13}$ Ibid., 120.

\begin{tabular}{l|l}
450 & $\begin{array}{l}\text { al-Daulah } \\
\text { Vol. 4. no.2. Oktober 20 I4 }\end{array}$
\end{tabular} 
mengalami kesalahan. Maka yang mempunyai hak untuk membuat peraturan hanya Allah semata. ${ }^{14}$

Melihat dari tiga alasan tersebut, setiap negara yang menjadikan sistem demokrasi sebagai sistem formal, maka dianggap sudah keluar dari koridor syari'ah. Dengan demikian, menurut Abdul Qadim Zallum sistem demokrasi merupakan bagian dari sistem kufur yang tidak layak diaplikasikan dalam bentuk negara muslim atau mayoritas penduduk muslim. ${ }^{15}$

\section{Pengertian dan Sejarah Majelis Umat}

Majelis Umat adalah majelis yang beranggotakan orang-orang yang mewakili kaum Muslim dalam memberikan pendapat sebagai tempat merujuk bagi Khalifah (pemimpin negara) untuk meminta masukan atau nasehat mereka dalam berbagai urusan. Mereka mewakili umat dalam melakukan kontrol dan mengoreksi (muhasabah) para pejabat pemerintah (al Hukkam). ${ }^{16}$

Keberadaan majelis ini diambil dari aktivitas Nabi yang sering meminta pendapat atau bermusyawarah dengan beberapa orang dari kaum Muhajirin dan kaum Anshar yang mewakili kaum mereka. Hal ini juga diambil dari perlakuan khusus Rasulullah Saw. terhadap orang-orang tertentu di antara para sahabat beliau untuk meminta masukan dari mereka. Di antara mereka adalah Abu bakar, Umar, Hamzah, Ali, Salman al Farisi, Hudzaifah.

Keberadaan lembaga Majelis Umat juga diambil dari perlakuan khusus Abu Bakar terhadap beberapa orang dari kaum Muhajirin dan Anshar untuk menjadi rujukannya dalam meminta pendapat mereka jika terjadi suatu persoalan. Ahlu Syura (musyawarah) pada masa kepemimpinan Abu bakar adalah para ulama dan orang-orang yang ahli dalam masalah fatwa. ${ }^{17}$

\footnotetext{
${ }^{14}$ Ibid., 121 .

${ }^{15}$ Ibid., 202.

${ }^{16}$ Abdul Qadim Zallum, Sistem Pemerintahan Islam, 267.

${ }^{17} \mathrm{lbid}, \mathrm{Q} 268$.
} 
Demikian juga terdapat sejumlah dalil yang menyeru kaum muslim untuk mengontrol dan mengoreksi penguasa (muhasabah al-hakim). Kaum muslim telah benar-benar menjalankan aktifitas mengoreksi para pejabat pemerintah itu pada masa Khulafaur Rasyidin.

Sebagaimana umat memiliki hak untuk mengangkat wakil dalam menjalankan syura, umat juga berhak mengangkat wakil dalam menjalankan aktifitas muhasabah. Semua itu menunjukkan kebolehan untuk membentuk majelis yang secara khusus mewakili umat dalam mengontrol dan mengoreksi para pejabat pemerintah dan dalam menjalankan musyawarah yang telah ditetapkan di dalam al-Qur'an dan as-Sunnah. Majelis itu diberi nama Majelis Umat karena majelis tersebut merupakan wakil umat dalam melakukan muhasabah (koreksi dan kontrol) dan syura (musyawarah).

Pada masa Nabi juga, beliau membentuk Majelis Syura (Majelis Umat) untuk memusyawarahkan hal-hal tertentu, yang anggotanya terdiri dari tujuh orang dari Muhajirin dan tujuh orang Anshar antara lain: Hamzah, Abu Bakar, Ja'far, Umar, Ali, Ibnu Mas'ud, Salman, Ammar, Huzaifah, Abu Dzarr, dan Bilal. ${ }^{18}$

\section{Proses Pemilihan Majelis Umat}

Para anggota Majelis Umat dipilih melalui pemilihan umum, bukan dengan aklamasi atau pengangkatan. Karena status mereka adalah mewakili semua rakyat dalam menyampaikan pendapat. Sedangkan seseorang yang menjadi wakil itu hakikatnya hanya akan dipilih oleh orang yang mewakilkan. Orang yang menjadi wakil tersebut sama sekali tidak bisa memaksa orang yang mewakilkan. Karena anggota majelis umat merupakan wakil semua orang dalam menyampaikan pendapat, baik secara pribadi maupun secara kolektif. ${ }^{19}$

18 M. Suaib Didu, Radikalisme dalam Islam (Antara Argumentasi Jihad dan Terorisme), (Jakarta: Relawan Bangsa, 2006), 32.

${ }^{19}$ Abdul Qadim Zallum, Sistem Pemerintahan Islam, 275. 
Tujuan adanya ahli syura itu adalah mewakili semua orang secara representatif, maka dasar yang dijadikan pijakan dalam memilih anggota majelis umat itu adalah harus mewakili semua orang secara representatif, sebagaimana menjadi pijakan Nabi saat memilih para pemimpin. Serta harus mewakili jama'ah, sebagaimana yang menjadi pijakan beliau saat memilih sebagian kaum Muhajirin dan sebagian lain dari kalangan Anshar. Sedangkan agar orang-orang yang tidak dikenal tersebut bisa mewakili individu dan kelompok, maka hanya bisa dilakukan dengan cara pemilihan. Karena itu, pemilihan umum untuk memilih anggota majelis umat itu merupakan suatu keharusan.

Dengan demikian, anggota majelis umat adalah para wakil dalam menyampaikan aspirasi umat. Sedangkan illat yang menjadi dasar pembentukan majelis umat adalah mewakili individu dan kelompok dalam menyampaikan pendapat serta melakukan koreksi. Karena illat tersebut tidak terdapat pada orang-orang yang tidak dikenal. Kecuali dengan melalui pemilihan umum maka semua anggota majelis umat tersebut harus dipilih melalui proses pemilihan umum. Bukan dengan cara ditunjuk sehingga benar-benar menjadi wakil.20

Untuk memudahkan praktek pemilu dan agar masyarakat tidak disibukkan dengan urusan pemilihan karena pemilu yang dilakukan berulang-ulang, maka terlebih dahulu dipilih para anggota majelis Wilayah. Kemudian mereka yang terpilih menjadi anggota Majelis Wilayah itu duduk bersama untuk memilih di antara mereka orang yang akan menjadi anggota Majelis Umat. Artinya, anggota Majelis Wilayah dipilih secara langsung oleh masyarakat. Sedangkan anggota Majelis Umat dipilih oleh dan dari anggota Majelis Wilayah. Ini berarti, awal dan berakhirnya keanggotaan Majelis Umat sama dengan awal dan berakhirnya keanggotaan majelis Wilayah.

${ }^{20} \mathrm{Ibid}, 276$.

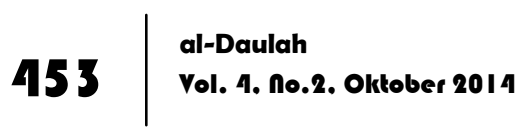


Anggota Majelis Wilayah yang terpilih menjadi anggota Majelis Umat, posisinya sebagai anggota Majelis Wilayah digantikan oleh orang yang mendapatkan suara terbanyak pada waktu pemilihan anggota Majelis Wilayah, namun ketika itu ia gagal menjadi anggota Majelis Wilayah. Jika ada dua orang atau lebih yang memiliki jumlah suara yang sama maka diundi di antara mereka. ${ }^{21}$

\section{Keanggotaan dan Masa Keanggotaan Majelis Umat}

Setiap muslim yang memiliki kewarganegaraan Daulah Khilafah, jika ia sudah baligh dan berakal sehat, maka memiliki hak untuk dipilih menjadi anggota Majelis Umat dan memiliki hak untuk memilih anggota Majelis Umat, baik laki-laki maupun perempuan. Keberadaan Majelis Umat tersebut merupakan lembaga legislatif yang mempunyai hak kontrol dan memberi masukan terhadap pemerintah. ${ }^{22}$

Non muslim pun mempunyai hak untuk dipilih menjadi majelis Umat dan juga berhak memilihnya, karena Majelis Umat semata-mata merupakan wakil rakyat dalam menyampaikan aspirasi dan tidak lebih. Semua orang yang hidup dalam naungan negara Islam berhak mewakilkan kepada siapa saja yang mereka kehendaki, yaitu orang-orang yang secara syar'i memang layak untuk menerima hak-hak wakalah tersebut. ${ }^{23}$

Sebagaimana setiap muslim memiliki hak untuk menyampaikan pendapat, maka demikian pula bagi orang non muslim. Dia juga mempunyai hak untuk menyampaikan suara dalam rangka menerapkan hukum-hukum Islam terhadap dirinya, termasuk masalah kedzaliman penguasa terhadap mereka, pengaduan tentang buruknya penerapan Islam terhadap mereka,

${ }^{21}$ Hizbut Tahrir, Struktur Negara Khilafah: Pemerintahan dan Administrasi, terj. Yahya A. R., (Jakarta: HTI-Press, 2006), 258.

22 Ibid., 258.

${ }^{23}$ Taqiyuddin An-Nabhani, Nidhamul Islami, (Al-Quds: Mansyurat Hizbut Tahrir, Cet. 5, 1953), 110. 
atau dalam masalah tidak tersedianya berbagai pelayanan bagi mereka dan yang semisal. ${ }^{24}$

Oleh karena itu, masing-masing warga negara Islam mempunyai hak untuk menyampaikan pendapatnya secara langsung maupun memiliki wakil untuk menyampaikan pendapatnya serta pendapat orang yang dipilihnya. Karena Allah menyerukan Islam ini kepada seluruh manusia dalam kapasitasnya sebagai manusia semata. ${ }^{25}$

Hanya saja, ada perbedaan terhadap orang non muslim yang tidak boleh menyampaikan pendapat dalam masalah perundangundangan, karena undang-undang yang Islami hanya dapat digali dari akidah Islam, sebab ia merupakan hukum-hukum syara' yang bersifat operasional, yang digali dari dalil-dalil yang rinci. Di samping karena ia merupakan hukum yang berfungsi untuk memecah setiap masalah manusia, sesuai dengan pandangan hidup tertentu yang telah ditentukan oleh akidah Islam. Padahal orang non Islam tersebut jelas memeluk akidah yang bertentangan dengan pandangan hidup Islam. Sehingga pendapatnya dalam masalah perundang-undangan tidak bisa diakomodasi.

Orang non muslim pun tidak dapat membatasi calon Khalifah dan di antara calon-calon tersebut kemudian dipilih menjadi Khalifah. Sebab dia tidak memiliki hak dalam urusan pemerintah. Sedangkan wewenang-wewenang Majelis Umat yang lain, status mereka sama dengan orang muslim termasuk dalam hal menyampaikan pendapat. ${ }^{26}$

Majelis Umat merupakan lembaga kontrol terhadap pemerintah yang mempunyai anggota perwakilan dari beberapa komunitas atau rakyat. Masa jabatan dari anggota Majelis Umat itu terbatas. ${ }^{27}$ Setiap anggota Majelis Umat bukan untuk seumur

\footnotetext{
${ }^{24}$ Hizbut Tahrir, Struktur Negara Khilafah: Pemerintahan dan Administrasi, 247-248.

25 Taqiyuddin An-Nabhani, Sistem Pemerintahan Islam dan Realitas Doktrin, Sejarah, Empirik, (Bangil: Al-Izzah, 1996), 299.

${ }^{26}$ Abdul Qadim Zallum, Sistem Pemerintahan Islam, 277-280.

27 Ibid., 276.
} 
hidup akan tetapi ada waktu tertentu yang menjadikan mereka untuk menjadi wakil rakyat guna menyalurkan aspirasinya. Dalam hal ini dapat diadopsi agar masa keanggotaan Majelis Umat tersebut dibatasi dengan lima tahun. ${ }^{28}$

\section{Fungsi dan Wewenang Majelis Umat}

Setiap lembaga mempunyai fungsi dan wewenang. Seperti Majelis Umat juga memiliki wewenang sebagaimana berikut:

a. Memberikan masukan pada khalifah. Masukannya berupa aktivitas dan masalah-masalah praktis, yang tidak memerlukan penelitian dan analisis, misalnya masalah pemerintahan, pendidikan, kesehatan, ekonomi, perdagangan, industri, pertanian dan seginya. Dalam hal ini pendapatnya bersifat mengikat.

b. Mengenai masalah-masalah pemikiran, yang memerlukan penelitian dan analisis, serta masalah-masalah disipliner, finansial, pasukan politik luar negeri, khalifah berhak merujuk pada majelis untuk meminta pendapatnya dan bersikap sesuai dengan pendapatnya. Sementara pandangannya majelis dalam hal ini bersifat tidak mengikat.

c. Khalifah boleh menyodorkan hukum-hukum dan undangundang yang ingin diadopsi kepada majelis umat. Anggota majelis yang Muslim mempunyai hak untuk memberikan masukan dan menjelaskan mana yang benar dan mana yang salah. Sedangkan non muslim tidak mempunyai hak yang sama dengan anggota majelis dari kalangan muslim. Hanya dalam hal ini pandangan mereka tidak mengikat.

d. Majelis juga mempunyai hak mengoreksi khalifah, atas seluruh tindakan yang secara riil terjadi di negara, baik masalah dalam dan luar negeri, finansial, masukan atau pun yang lain. Pandangan majelis mengikat jika suara mayoritas dalam

${ }^{28}$ Hizbut Tahrir, Struktur Negara Khilafah: Pemerintahan dan Administrasi, 262.

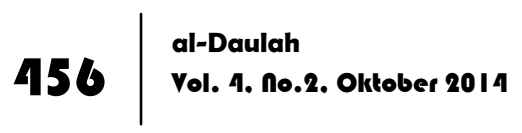


masalah ini bersifat mengikat dan pandangan majelis tidak mengikat jika mayoritas suara tidak mengikat.

Jika majelis berbeda pendapat dengan khalifah, mengenai tindakan yang secara riil sudah dilaksanakan, berdasarkan pertimbangan hukum syara', maka dalam hal ini harus diserahkan kepada mahkamah madhalim (Mahkamah Konstitusi; Indonesia) untuk memastikannya, dari aspek sesuai dan tidaknya dengan hukum syara'. Keputusan mahkamah madhalim dalam hal ini bersifat mengikat.

e. Majelis Umat berhak untuk menampakkan ketidak sukaannya terhadap para mu'awin, wali dan amil. Dalam hal ini pendapat majelis bersifat mengikat. Bagi seorang khalifah ketika itu harus memberhentikan mereka.

f. Kaum muslimin yang menjadi anggota majelis umat berhak untuk membatasi calon yang akan menjadi khalifah. Dalam hal ini suara mereka bersifat mengikat, sehingga calon lain selain yang telah dicalonkan majelis umat tersebut tidak dapat diterima. ${ }^{29}$

\section{Dewan Perwakilan Rakyat (DPR)}

DPR (Dewan Perwakilan Rakyat) ialah lembaga tinggi negara dan merupakan wahana (alat kenegaraan) untuk melaksanakan demokrasi Pancasila. ${ }^{30}$ Lembaga legislatif (DPR) adalah lembaga yang ditetapkan membuat peraturan perundang-undangan, tetapi berbeda bentuknya pada masing-masing negara. Di Indonesia disebut dengan DPR RI (Dewan Perwakilan Rakyat Republik Indonesia) untuk tingkat pusat, dan DPRD (Dewan Perwakilan Rakyat Daerah) untuk tingkat daerah, baik tingkat I maupun tingkat II. ${ }^{31}$ Lembaga legislatif ini, merupakan badan atau lembaga yang didalamnya terdapat sistem yang berlandaskan Pancasila

\footnotetext{
${ }^{29}$ Abdul Qadim Zallum, Sistem Pemerintahan Islam, 280-28I .

${ }^{30}$ C.S.T. Kansil, Hukum Tata Negara Republik Indonesia, (Jakarta: Rineka Cipta, 2003), I 56.

${ }^{3}$ I Inu Kencana Syafiie, IImu Politik, (Jakarta: Rineka Cipta, 20 I0), I 25.
} 
pada sila ke-empat yaitu pengambilan mufakat dalam memutuskan suatu persoalan dalam tingkat nasional. ${ }^{32}$

Ide pembentukan badan perwakilan rakyat pada dasarnya bermula dari keperluan masyarakat akan hukum sebagai sarana untuk mengatur kehidupan bersama di samping kebutuhannya akan badan yang membuat dan memberlakukannya. Selaras dengan ide tersebut, penguasa suatu negara secara keseluruhan membuat hukum atas nama rakyatnya dan memberlakukannya untuk menyelenggarakan kehidupan bersama.

Proses pemilihan DPR telah diatur dalam Undang-Undang No. 12 Tahun 2003 tentang Pemilihan Umum Anggota DPR, DPD dan DPRD. ${ }^{33}$ Adapun untuk menjadi anggota DPR harus mempunyai beberapa kriteria, diantaranya harus bertempat tinggal dalam wilayah negara Republik Indonesia. Keanggotaan DPR diresmikan dengan Keputusan Presiden. ${ }^{34}$ Masa keanggotaan DPR adalah lima tahun, mereka berhenti bersama-sama setelah masa keanggotaannya berakhir. ${ }^{35}$

Seluruh anggota DPR mempunyai kewajiban mengawasi tindakan-tindakan presiden dalam rangka menjalankan haluan negara yang ditetapkan dalam GBHN. Apabila DPR menganggap presiden benar-benar melanggar haluan negara, maka DPR menyampaikan memorandum (peringatan) untuk mengingatkan Presiden. Jika dalam waktu tiga bulan presiden tidak memperhatikan memorandum DPR tersebut, maka DPR menyampaikan memorandum yang kedua. Jika dalam waktu satu bulan memorandum yang kedua ini tidak diindahkan oleh presiden, maka DPR dapat meminta MPR mengadakan sidang istimewa untuk meminta pertanggung jawaban presiden.

\footnotetext{
${ }^{32}$ Douglas E. Ramage, Percaturan Politik di Indonesia (Demokrasi, Islam, dan Ideologi Toleransi), (Yogyakarta: Mata Bangsa, 2002), 23.

33 Undang-Undang No. 12 Tahun 2003 Tentang Pemihan Umum, 27-32.

${ }^{34}$ C.S.T. Kansil, Hukum Tata Negara Republik Indonesia, 168.

${ }^{35}$ Ibid., 168-169.
} 


\section{Analisis Komparatif Majelis Umat dan DPR: Peran, Fungsi, dan} Posisinya

Majelis Umat merupakan majelis yang beranggotakan orangorang yang mewakili kaum Muslim dalam memberikan pendapat sebagai tempat merujuk bagi Khalifah untuk meminta masukan atau nasehat mereka dalam berbagai urusan

Keberadaan majelis ini diambil dari aktivitas Nabi yang sering meminta pendapat atau bermusyawarah dengan beberapa orang dari kaum Muhajirin dan kaum Anshar yang mewakili kaum mereka. Realitas majelis Umat juga diambil dari perlakuan khusus Abu Bakar terhadap beberapa orang dari kaum Muhajirin dan Anshar untuk menjadi rujukannya dalam meminta pendapat mereka jika terjadi suatu persoalan.

Sedangkan Lembaga legislatif (DPR) adalah lembaga yang ditetapkan membuat peraturan perundang-undangan, tetapi sudah barang tentu berbeda bentuknya pada masing-masing negara. Di Indonesia disebut dengan DPR RI (Dewan Perwakilan Rakyat Republik Indonesia) untuk tingkat pusat, dan DPRD (Dewan Perwakilan Rakyat Daerah) untuk tingkat daerah, baik tingkat I maupun tingkat II.

Ide pembentukan badan perwakilan rakyat pada dasarnya bermula dari keperluan masyarakat akan hukum sebagai sarana untuk mengatur kehidupan bersama di samping kebutuhannya akan badan yang membuat dan memberlakukannya. Selaras dengan ide tersebut, penguasa suatu negara secara keseluruhan membuat hukum atas nama rakyatnya dan memberlakukannya untuk menyelenggarakan kehidupan bersama. Di sini walaupun penguasa negara sudah dibagi berdasarkan penugasan-penugasan tertentu, namun dalam hal pembuatan hukum semua pihak melibatkan diri.

Dengan demikian, pada dasarnya dari keberadaan Majelis Umat dan DPR, merupakan wakil rakyat yang mempunyai kewenangan penuh dalam kaitannya dengan kepentingan publik secara universal, baik kepentingan individu maupun kepentingan 
kolektif. Sebagai kontrol dan menyalurkan aspirasi rakyat terhadap pemerintah.

Setiap keanggotaan dalam lembaga negara manapun tidak terlepas dari prosedur yang menjadi acuan, demi menjaga stabilitas pemilihan. Begitu juga dalam proses pemilihan anggota legislatif (DPR) di Indonesia sudah diatur dalam undang-undang nomor 12 tahun 2003 tentang pemilihan umum (PEMILU). Pasal 65, pasal 67, pasal 68, pasal 69, pasal 70. Dan lembaga yang menjadi penyelenggara atau yang menjalankan tugas dalam melaksanakan pemilihan umum adalah Komisi Pemilihan Umum (KPU). Setiap daerah (propinsi, kota, kabupaten) ada KPU yang menyelenggarakan sekaligus menjadi pelaksana pemilu.

Anggota Majelis Umat dipilih melalui pemilihan umum, bukan dengan penunjukan atau pengangkatan. Karena status mereka adalah mewakili semua rakyat dalam menyampaikan pendapat mereka. Sedangkan seorang wakil itu hakikatnya hanya akan dipilih oleh orang yang mewakilkan. Orang yang menjadi wakil tersebut sama sekali tidak bisa memaksa orang yang mewakilkan. Karena anggota majelis umat merupakan wakil semua orang dalam menyampaikan pendapat, baik secara pribadi maupun secara kolektif. Sedangkan untuk mengetahui wakil dalam suatu wilayah yang luas di mana orang-orang tersebut tidak dikenal, jelas tidak akan mungkin dilakukan kecuali oleh orang yang memilihnya untuk menjadi wakil.

Walaupun dalam memilih anggota Majelis Umat dengan melalui pemilu, tapi dalam sistem pemerintahan Khilafah tidak ada lembaga yang menjadi wadah untuk menyelenggarakan pemilihan umum dalam penjaringan wakil rakyat (anggota Majelis Umat).

Untuk memudahkan praktek pemilu dan agar masyarakat tidak disibukkan dengan urusan pemilihan, karena pemilu yang dilakukan berulang-ulang, maka terlebih dahulu dipilih para anggota Majelis Wilayah. Kemudian mereka yang terpilih menjadi anggota Majelis Wilayah itu duduk bersama untuk memilih di 
antara mereka orang yang akan menjadi anggota Majelis Umat. Artinya, anggota Majelis Wilayah dipilih secara langsung oleh masyarakat dan anggota Majelis Umat dipilih oleh dan dari anggota Majelis Wilayah. Tapi dalam sistem pemilihannya tidak diatur dalam Undang-undang secara jelas. Hanya saja pemilihan tersebut mengambil perwakilan dari setiap kelompok, seperti Anshar dan Muhajirin. Ini merujuk pada kebiasaan nabi Muhammad Saw ketika meminta pendapat pada kaum tersebut di masa itu.

Kekuasaan dalam sistem pemerintahan demokrasi terbagi menjadi tiga institusi yang memiliki kewenangan berbeda-beda, yakni: kekuasaan legislatif (DPR), kekuasaan eksekutif (kekuasaan untuk menjalankan undang-undang), dan kekuasaan yudikatif (kekuasaan untuk mengadili atas pelanggaran undang-undang). Konsep pembagian kekuasaan ini dikenal dengan trias politica. Pembagian kekuasaan itu dimaksudkan untuk mencegah dominasi kekuasaan oleh seseorang atau lembaga tertentu sehingga kedaulatan rakyat dapat terjaga.

Dalam sistem Khilafah, kekuasaan ada di tangan umat. Seorang Khalifah hanya bisa memiliki kekuasaan melalui baiat. Kesimpulan ini didasarkan pada hadis-hadis tentang baiat yang semuanya menunjukkan bahwa baiat itu diberikan oleh kaum Muslim kepada khalifah, bukan oleh khalifah kepada kaum Muslim. Ini menunjukkan bahwa Islam telah menjadikan kekuasaan di tangan umat. Artinya, umat berhak mengangkat siapa saja yang mereka pilih dan mereka baiat untuk menjadi Khalifah.

Keanggotaan Dewan Perwakilan Rakyat dan Majelis Umat pada dasarnya tidak ada perbedaan yang signifikan. Persamaan dari keduanya adalah sama-sama menjadi wakil rakyat, sebagai kontrol terhadap pemerintah, walau pun dalam wewenangnya ada sedikit perbedaan.

Perbedaan kelamin tidak menjadi persoalan, baik laki-laki maupun perempuan, karena jabatan ini bukan termasuk dari 
pihak pemerintahan, juga tidak masuk dalam cakupan hadits yang tidak membolehkan seorang perempuan menjadi pemimpin. Akan tetapi keberadaan Majelis Umat tersebut merupakan lembaga legislatif yang mempunyai hak kontrol dan memberi masukan terhadap pemerintah. Muslim atau non muslim dapat menjadi anggota DPR dan Majelis Umat. Yang menjadi syarat utama bagi anggota legislatif adalah harus bertempat tinggal di wilayah negara kekuasaan yang mereka beri kepercayaan.

Orang non muslim yang menjadi warga Daulah boleh menjadi anggota Majelis Umat. Hal itu dalam rangka menyampaikan pengaduan tentang kezaliman penguasa kepada mereka, atau pengaduan tentang buruknya penerapan hukum Islam terhadap mereka, atau dalam masalah tidak tersedianya berbagai pelayanan bagi mereka dan yang semisal.

Sedangkan keanggotaan dalam legislatif mempunyai masa jabatan dengan batasan-batasan tertentu. Karena pada masa Rasul, orang-orang yang selalu dimintai pendapat oleh Rasulullah tidak lagi menjadi tempat rujukan Abu Bakar dalam meminta pendapat. Begitu juga Umar. Beliau tidak lagi menjadikan rujukan orangorang yang telah menjadi rujukan Abu Bakar dalam meminta pendapat. Bahkan, Umar pada akhir kepemimpinannya telah merujuk kepada pendapat orang-orang yang berbeda dengan masa awal beliau menjadi pemimpin.

Sedangkan masa keanggotaan DPR adalah lima tahun, mereka berhenti bersama-sama setelah masa keanggotaannya berakhir. Pada saat anggota DPR yang baru diambil sumpah atau janjinya oleh pejabat yang berwenang, semua anggota DPR yang lama berakhir keanggotaannya.

Setiap lima tahun sekali wakil rakyat (legislatif), Majelis Umat maupun DPR diadakan pergantian dengan melalui Pemilihan Umum. Jadi, masa bakti Majelis Umat dan DPR sama-sama mempunyai batasan-batasan waktu tertentu. 


\section{Analisis Komparatif Eksistensi Majelis Umat dan DPR}

Dalam negara demokrasi, wakil rakyat menjalankan kedaulatan rakyat. Lembaga perwakilan rakyat inilah yang menetapkan semua hukum dan peraturan dalam negara tersebut. Di beberapa negara, parlemen ini juga memiliki wewenang meminta pertanggungjawaban kepala negara.

Itu sangat berbeda dengan wakil rakyat dalam sistem Khilafah. Wakil rakyat yang terwadahi dalam Majelis Umat sama sekali tidak berfungsi sebagai lembaga legislatif. Dalam Islam, kekuasaan legislatif hanya milik Allah Swt. semata, bukan milik manusia. Kalau pun ada hak mengadopsi hukum-hukum yang berkaitan dengan pengaturan urusan rakyat dan pemerintahan, maka itu adalah bagi khalifah. Ini bukan berarti khalifah memegang kekuasaan legislatif. Sebab, khalifah tidak membuat hukum sendiri, namun hanya sekadar mengambil hukum-hukum syariat yang terkandung dalam kitabullah dan sunnah Rasul-Nya berdasarkan kriteria dalil melalui proses ijtihad yang benar.

Dalam mengadopsi hukum syariat menjadi undang-undang, khalifah diperbolehkan mengajukannya kepada Majelis Umat untuk meminta pendapatnya mengenai masalah tersebut. Akan tetapi, pendapat majelis dalam masalah ini tidak mengikat. Tugas utama anggota Majelis Umat hanyalah mewakili aspirasi kaum Muslim agar menjadi pertimbangan Khalifah dan tempat Khalifah meminta masukan dalam urusan kaum Muslim. Mereka juga mewakili umat melakukan muhasabah (kontrol dan koreksi) terhadap pejabat pemerintahan. ${ }^{36}$

Dalam keanggotaan Majelis Umat, Muslim maupun Non muslim pun mempunyai hak untuk dipilih menjadi anggota dan juga berhak memilihnya, karena Majelis Umat semata-mata merupakan wakil rakyat dalam menyampaikan aspirasi dan tidak lebih. Majelis tersebut tidak memiliki wewenang untuk memerintah serta umat dalam menyampaikan pendapat, tentu

36 Rohmadi, Studi Komparatif Negara Islam Dan Negara Sekular, diakses dari http:www.englishdiari.net. 
semua orang yang hidup dalam naungan negara Islam berhak mewakilkan kepada siapa saja yang mereka kehendaki, yaitu orang-orang secara syar'i memang layak untuk menerima hak-hak wakalah tersebut.

Sebagaimana setiap muslim memiliki hak untuk menyampaikan pendapat, maka demikian pula bagi orang non muslim. Dia juga mempunyai hak untuk menyampaikan suara dalam rangka menerapkan hukum-hukum Islam terhadap dirinya, termasuk masalah kedaliman penguasa terhadap mereka.

Hanya saja, bedanya non muslim tidak boleh menyampaikan pendapat dalam masalah perundang-undangan, karena undangundang yang Islami hanya dapat digali dari akidah Islam, sebab ia merupakan hukum-hukum syara' yang bersifat operasional, yang digali dari dalil-dalil yang rinci. Disamping karena ia merupakan hukum yang berfungsi untuk memecah setiap masalah manusia, sesuai dengan pandangan hidup tertentu yang telah ditentukan oleh akidah Islam. Karena mereka (non Muslim) tersebut jelas memeluk akidah yang bertentangan dengan pandangan hidup Islam. Sehingga pendapatnya dalam masalah perundangundangan tidak bisa terakomudatif.

Non muslim tidak dapat membatasi calon Khalifah dan diantara calon-calon tersebut kemudian dipilih menjadi Khalifah. Sebab dia tidak memiliki hak dalam urusan pemerintah. Sedangkan wewenang-wewenang Majelis Umat yang lain, status mereka sama dengan orang muslim termasuk dalam hal menyampaikan pendapat.

Dalam sistem pemerintahan di Indonesia, Dewan Perwakilan Rakyat, tidak ada perbedaan dalam menjalankan tugasnya sebagai legislatif. Muslim atau non muslim sama-sama mendapatkan posisi yang setara. Baik dalam menyampaikan aspirasinya, pembentukan hukum atau perundang-undangan.

Berdasarkan uraian di atas, memang ada perbedaan sistem Khilafah dengan sistem pemerintahan demokrasi (Indonesia), terutama dalam kewenangan legislatif, dimana legislatif 
merupakan alat kontrol terhadap perjalanan pemerintah sekaligus menyampaikan aspirasi rakyat dalam kepentingan umum. Dari sisi lain, persamaan juga termuat dalam dua konsepsi tersebut.

\section{Penutup}

Konsepsi Majelis Umat menurut Abdul Qadim Zallum adalah lembaga atau majelis yang terdiri dari beberapa orang yang mewakili aspirasi rakyat khususnya umat Islam agar menjadi pertimbangan khalifah dan tempat khalifah meminta masukan dalam urusan kehidupan sehari-hari, mempunyai fungsi legislasi dan melakukan kontrol terhadap pemerintah. Akan tetapi, Majelis Umat tidak mempunyai peran aktif dalam pembentukan hukum, karena hukum yang diterapkan dalam negara sudah diadopsi dari al-Qur'an dan al-Hadits.

Konsepsi Dewan Perwakilan Rakyat (DPR) menurut Undangundang 1945, adalah lembaga tinggi negara dan merupakan wahana untuk melaksanakan demokrasi, membuat peraturan perundang-undangan serta sebagai alat kontrol terhadap pemerintahan. Semua anggota DPR mempunyai kewajiban mengawasi tindakan-tindakan presiden dalam rangka menjalankan haluan negara yang ditetapkan dalam GBHN.

Dalam pemikiran Abdul Qadim Zallum, tentang konsepsi Majelis Umat, yang menjadi lembaga kontrol terhadap pemerintah (Khalifah). Dalam kaitannya dengan Konsepsi Dewan Perwakilan Rakyat (DPR) di Indonesia menurut Undang-undang 1945 tidak terjadi perbedaan yang mendasar baik dalam sejarah terbentuknya, wewenang, keanggotaan dan masa jabatannya.

Proses pemilihan antara anggota Majelis Umat dan DPR terdapat perbedaan. Untuk memilih anggota Majelis Umat, terlebih dahulu dipilih anggota majelis wilayah, kemudian majelis wilayah tersebut duduk bersama (rapat, musyawarah) guna memilih anggota majelis umat. Dengan demikian, dalam pelaksanaan pemilu, tidak ditemukan prosedur atau Undangundang yang mengatur secara spesifik dan tidak ada lembaga 
pelaksana pemilihan. Sedangkan proses pemilihan anggota DPR sudah jelas dalam undang-undang nomor 12 tahun 2003 tentang pemilihan umum (PEMILU). Pasal 65, pasal 67, pasal 68, pasal 69, pasal 70.

\section{Daftar Pustaka}

Abdallah, Ulil Abshar. Islam dan Barat (Demokrasi dalam Masyarakat Islam). Jakarta: Diterbitkan kerjasama Friedrich-NaumanStiftung Indonesia dan Pusat Studi Islam Paramadina, 2002.

Didu, M. Suaib. Radikalisme dalam Islam (Antara Argumentasi Jihad dan Terorisme). Jakarta: Relawan Bangsa, 2006.

Hizbut Tahrir. Struktur Negara Khilafah: Pemerintahan dan Administrasi, terj. Yahya A. R., Jakarta: HTI-Press, 2006.

Kansil, CST. Hukum Tata Negara Republik Indonesia. Jakarta: Rineka Cipta, 2003.

Nabhani (an-), Taqiyuddin. Nidhamul Islami. Al-Quds: Mansyurat Hizbut Tahrir, Cet. 5, 1953.

-------. Sistem Pemerintahan Islam dan Realitas Doktrin, Sejarah, Empirik. Bangil: Al-Izzah, 1996.

Ramage, Douglas E. Percaturan Politik di Indonesia (Demokrasi, Islam, dan Ideologi Toleransi). Yogyakarta: Mata Bangsa, 2002.

Sanit, Arbi. Perwakilan Politik di Indonesia. Jakarta: Rajawali, 1985.

Syafiie, Inu Kencana. Ilmu Politik. Jakarta: Rineka Cipta, 2010.

Zallum, Abdul Qadim. Pemikiran Politik Islam. Bangil: Al-Izzah, 2001.

-. Sistem Pemerintahan Islam. Bangil: Al-Izzah, 2002.

Undang Undang Dasar 1945

Undang-Undang No. 12 Tahun 2003 Tentang Pemihan Umum.

Rohmadi. Studi Komparatif Negara Islam Dan Negara Sekular, http:www.englishdiari.net.

http:zantrum-demokratische-kultur.de/pdf/hisbut.pdf.

http.fahmy-ramadhan 